\title{
Insect Management for Onions, Leek, and Garlic ${ }^{1}$
}

\section{S. E. Webb²}

Sweet varieties of bulbing onions, which make bulbs under short day conditions and do not store well, are by far the most common onions grown in Florida. They are generally grown on small acreages in the winter for local and farmers markets. In Hillsborough County and in the Suwannee Valley, strawberry growers are the major producers of onions, many of which are harvested green.

Because it is grown in the winter and early spring, the onion crop in Florida suffers from relatively few insect pests, with thrips and seedcorn maggot being the most commonly found.

Armyworms and cutworms can occasionally damage seedlings. Cultural controls, such as growing thrips-tolerant varieties and preparing seedbeds early, should be used and insecticides avoided as much as possible to limit the development of insecticide resistance and favor the survival of insect predators and parasites.

Several species of thrips feed on onions. In north Florida, onion thrips (Thrips tabaci) and tobacco thrips (Frankliniella fusca) are the most commonly found. Onion thrips can transmit iris yellow spot virus and tobacco thrips transmits tomato spotted wilt virus to onions. Other thrips that have been reported to attack onions include western flower thrips ( $F$. occidentalis) and melon thrips (T. palmi). Thrips can become resistant to insecticides very quickly. Because they feed deep down at the base of emerging leaves, they can also avoid both insecticides and natural enemies, such as the insidious pirate bug. There are relatively few insecticides labeled for use on onions. The most commonly used are the pyrethroids and methomyl, a carbamate, but they may be only moderately effective. A threshold of 5-10 thrips per plant has been suggested for winter-grown sweet onions in the South.

Seedcorn maggots (Delia platura), which feed on many different plants, can be a problem when there are high levels of decaying organic matter in the soil and when the weather is cool and wet. Soil applications of chlorpyrifos or diazinon at planting may be useful if there is a history of seedcorn maggot problems. Early preparation of the field to allow the breakdown of organic matter before planting is essential.

1. This document is ENY-467 (IG153), one of a series of the Entomology \& Nematology Department, Florida Cooperative Extension Service, Institute of Food and Agricultural Sciences, University of Florida. Published: August 2002. Revised: September 2005. For more publications related to horticulture/agriculture, please visit the EDIS Website at http://edis.ifas.ufl.edu/.

2. S. E. Webb, associate professor, Entomology and Nematology Department, Cooperative Extension Service, Institute of Food and Agricultural Sciences, University of Florida, Gainesville, 32611-0640.

The use of trade names in this publication is solely for the purpose of providing specific information. UF/IFAS does not guarantee or warranty the products named, and references to them in this publication does not signify our approval to the exclusion of other products of suitable composition. All chemicals should be used in accordance with directions on the manufacturer's label. Use pesticides safely. Read and follow directions on the manufacturer's label. 


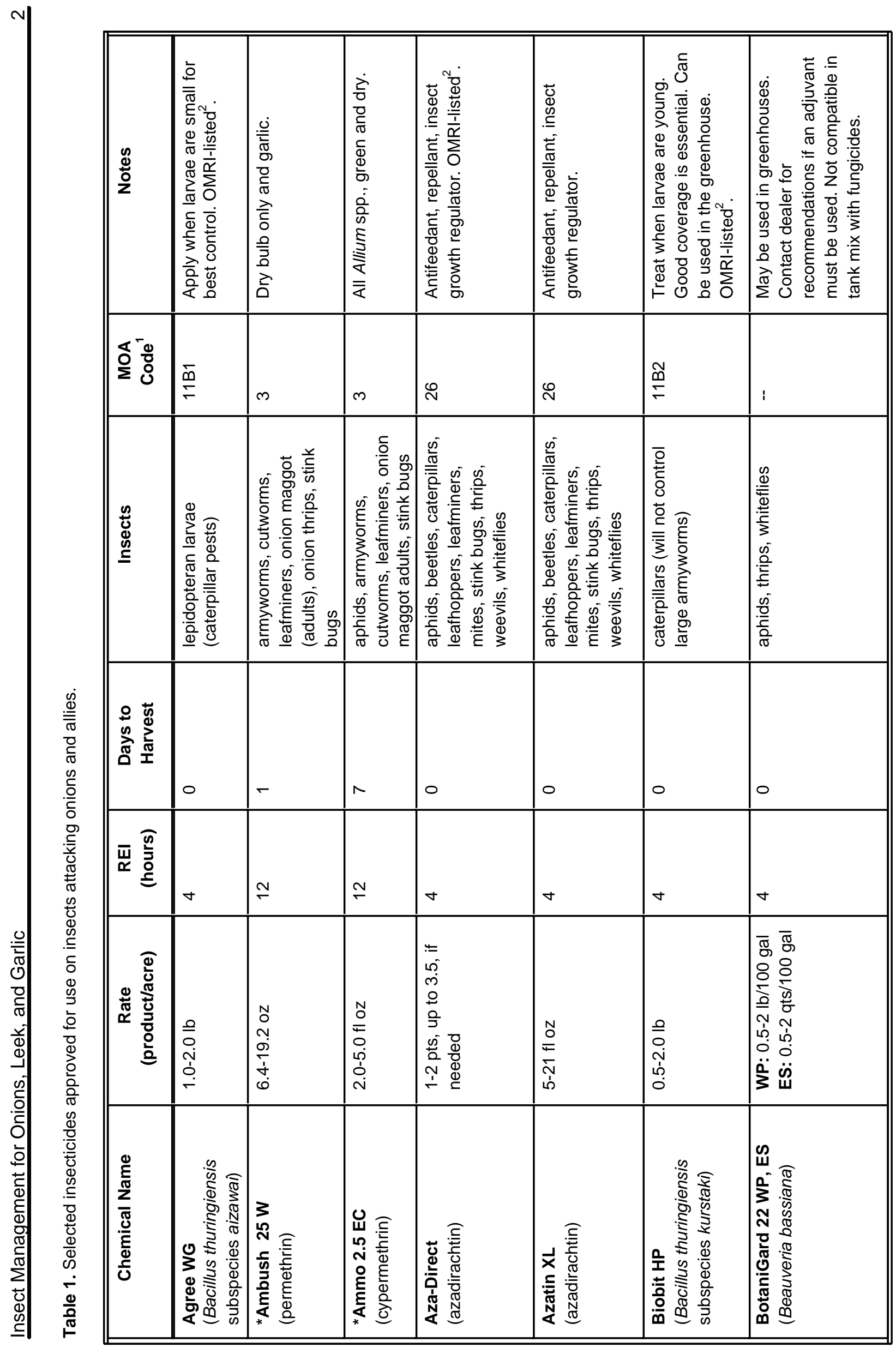




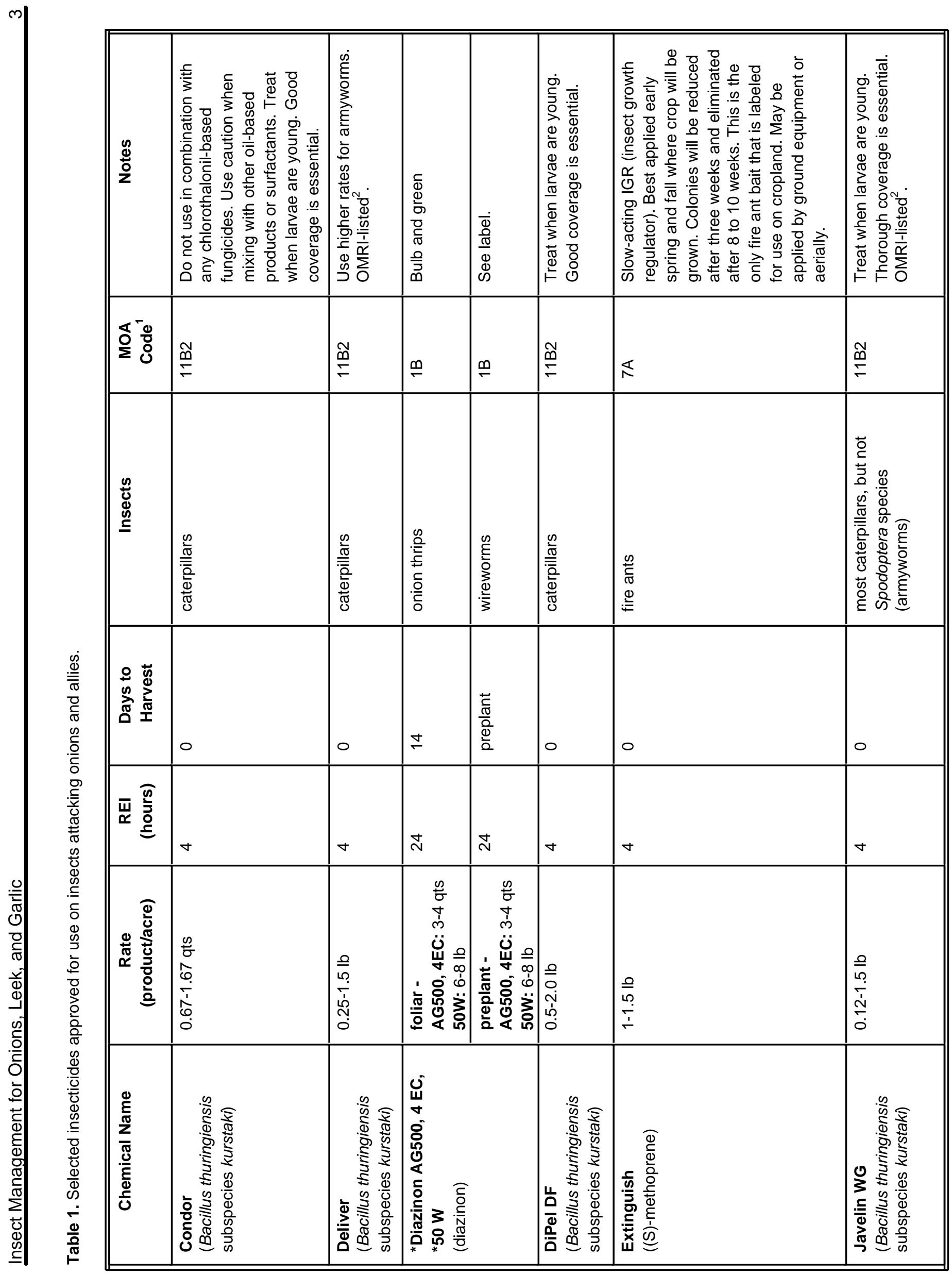




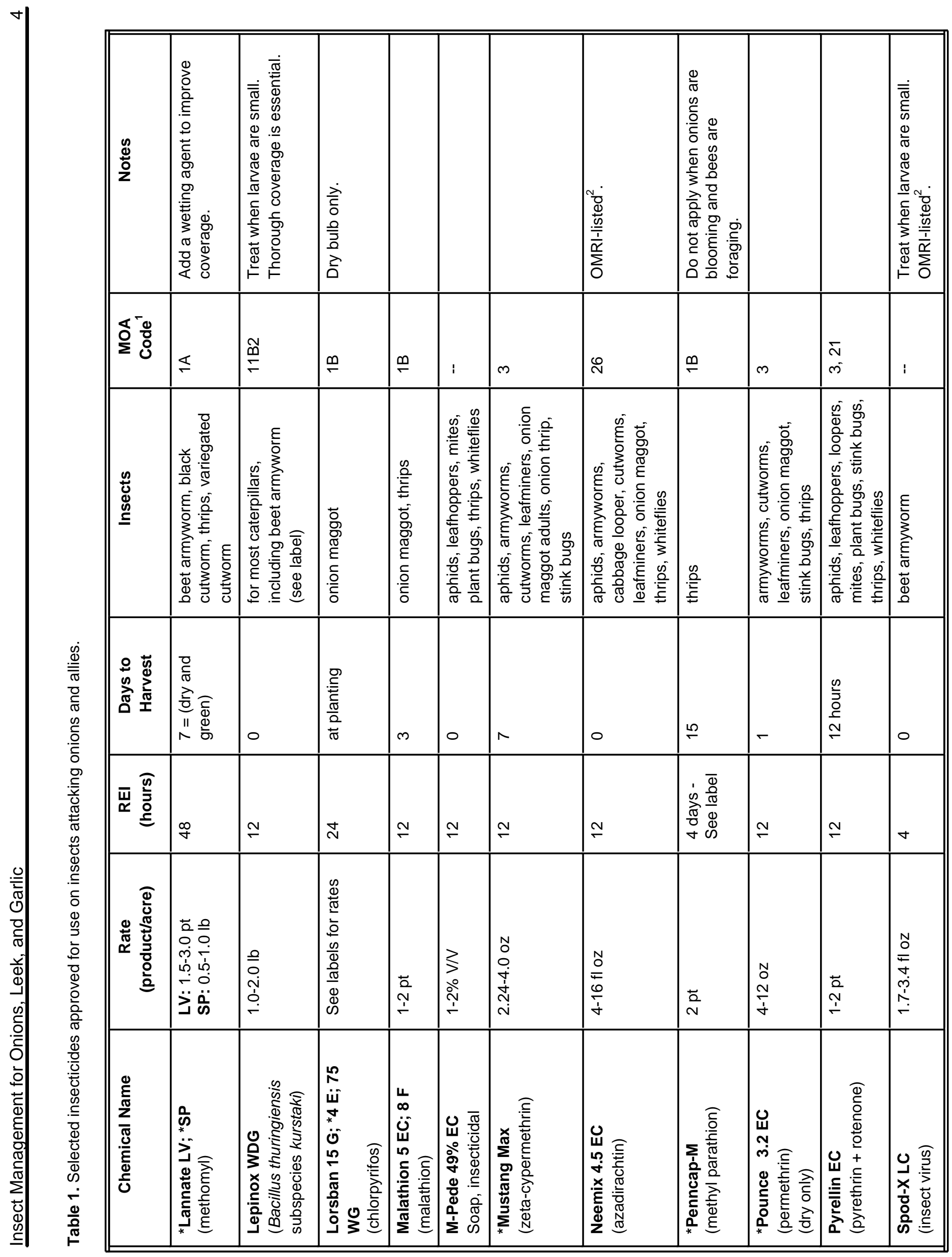




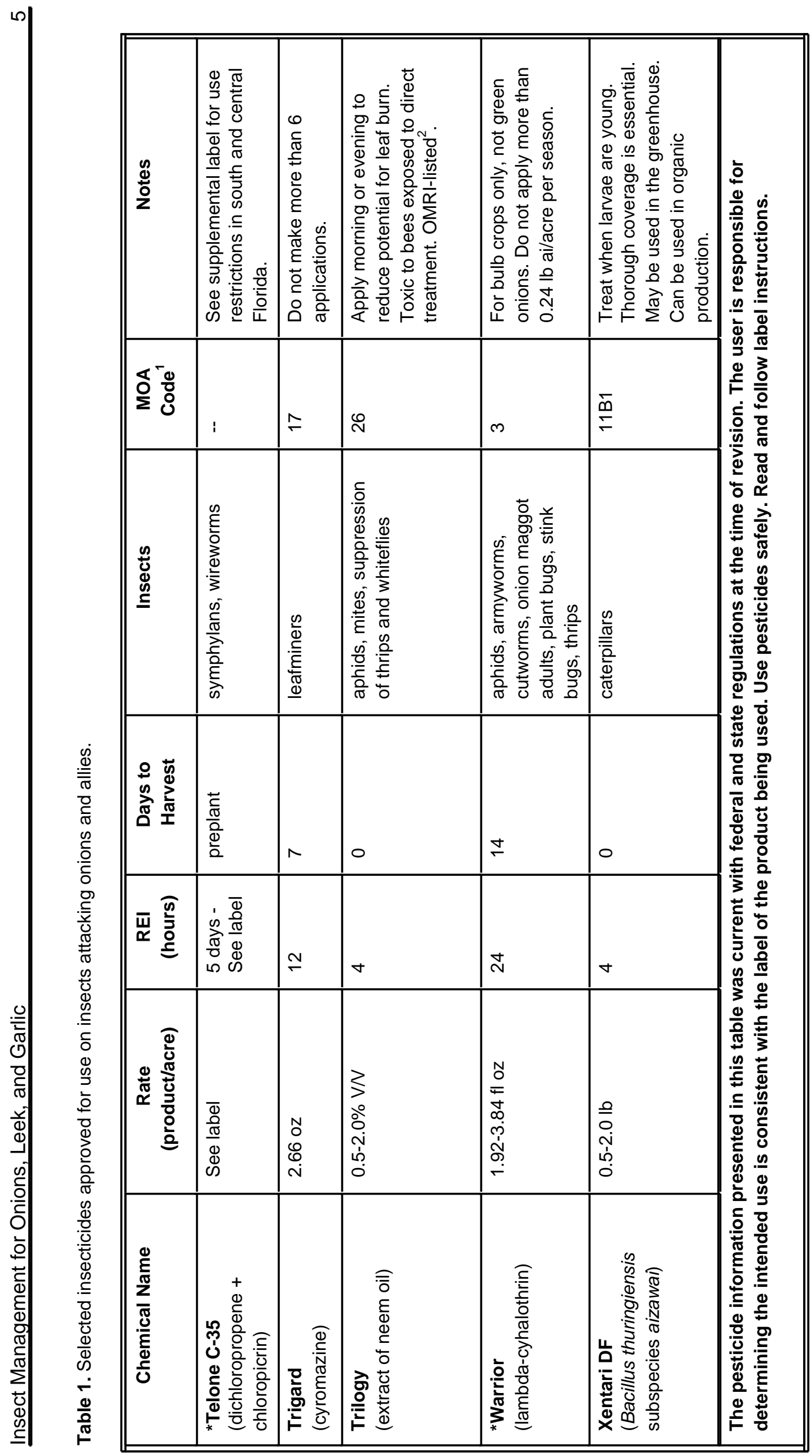




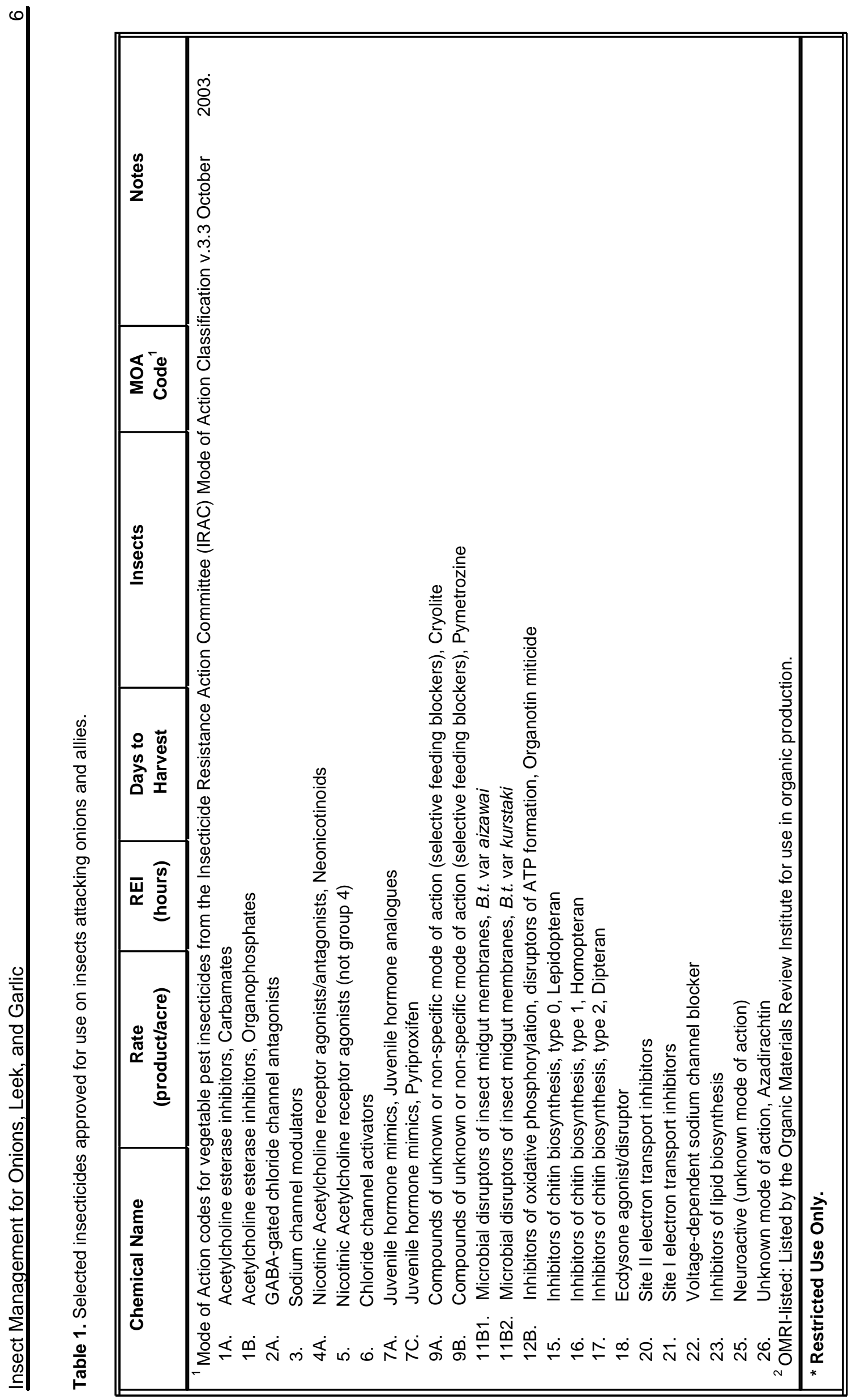

